\title{
Research on the Present Situation and Developing Strategy of Processing Trade Transformation in ZHU River Delta Region
}

\author{
Xuan Xu \\ College of Business, Hunan Agricultural University, Changsha, Hunan, China \\ E-mail: xuxuan418@126.com
}

Keywords: ZHU River Delta Region; Processing Trade Transformation; Upgrading

\begin{abstract}
Processing trade is an important part of the foreign trade in the ZHU River Delta, which is the main driving force for the sustained and healthy development of the ZHU River Delta. . However, due to the changes in domestic and overseas economic and social development environment, the transformation and upgrading of PRD processing trade are imminent. Based on the present development situation of ZHU River Delta area processing trade, this paper analyzes the transformation and upgrading of existing problems and their causes, puts forward the adjustment of the transformation and upgrading direction of the processing trade, and enables the processing trade in the ZHU River Delta region be more scientific and reasonable.Processing trade is the important part of the foreign trade in the ZHU River Delta region and the way of utilizing foreign capital is the main impetus to promote the sustained and healthy development of the ZHU River Delta region. Facing the new challenges brought by the international economic environment and the tremendous changes in the economic crisis to China's processing trade industry, in the transformation of the international external competition pressure and domestic development situation, shortages of labor and labor costs continued to rise coexistence of the processing trade, production cost rises suddenly, at the same time, it is restricted by international import and export demand decline in the volume of, the original pattern of industrial development. Therefore, the migration and transformation of the labor-intensive, low-cost dependent processing trade enterprises in the ZHU River Delta region have become an inevitable choice.
\end{abstract}

\section{The development of processing trade in zhu river delta region}

The ZHU River Delta region processing trade in the country occupies the main position. Processing trade is the most powerful industry in ZHU River Delta region, and it is also the key part of the economic growth of the region. In 2008, the total imports and exports of the ZHU River Delta region was $\$ 631175000000$, accounting for $21 \%$ of the country, which export $\$ 259521000000$, import $\$ 371654000000$. In 2009, the GDP of the ZHU River Delta region accounted for nearly $10 \%$ of the total GDP, and became the powerful driving force of economic development. In 2009, in the ZHU River Delta region of the import and export of processing trade 4018.05_yi billion, which exports 2571.52_yi billion dollars and imports 1446.53_yi billion US dollars, year the national processing trade import and export volume for 10534.91_yi billion, which exports 6751.14_yi billion dollars and imports 3783.77_yi billion, we can be seen in the processing trade in ZHU River Delta region import and export volume inlet, and exports accounted for $38.14 \%$ of the country and $38.23 \%$ and $38.09 \%$.

The gradual optimization of the export commodity structure in the ZHU River Delta region processing trade. From the beginning of twentieth Century and the two industry transfer in the early 90 "s, the formation of the three major industrial systems in the ZHU River Delta region played an important role. Because of that period, the ZHU River Delta region has the relative advantages of low labor resources, and all two industries are labor-intensive based. With the rise of a new round of IT industry transfer, multinational companies to invest in China increased, characteristics of the processing trade industry changing, technical level and the division of grades gradually improved, 
the processing trade began from labor intensive industries mainly gradually to technology intensive industry transition. In 2009, the processing trade in the ZHU River Delta exports of electromechanical products and high-tech products were respectively 279.3 billion and $\$ 15.819$ million, an increase of $24.5 \%$ and $21.8 \%$, accounted for $76.9 \%$ and $43.6 \%$ of the province's processing trade export, and the export processing trade is more concentrated in electromechanical and high-tech products. The proportion of high-tech products increases continuously in the process of processing trade export.

Foreign invested enterprises become the main body of processing trade. In recent years, the foreign investment in the ZHU River Delta region has become the main body of the processing trade, and its export structure is also constantly adjusted and optimized. At present, there are nearly 7 processing trade enterprises in the ZHU River Delta region, which takes foreign investment enterprises as the main body of the processing trade enterprise, accounting for more than $80 \%$, and domestic enterprises accounting for only $20 \%$. With the continuous development of the processing trade and the change of the investment environment, the more foreign capital companies have set up the R \& D institution in the ZHU River Delta region. By 2009, DuPont, Honda, Hitachi, Samsung, TCL and other well-known multinational corporations in the ZHU River Delta set up more than 300 R \& D institutions. These institutions for the ZHU River Delta region to undertake foreign high-level technology transfer, and enhance technological innovation, and thus achieve the upgrading of processing trade industry provided a good platform.

Zhu River Delta region industry and industry chain is at the low end of the industry chain. Since the investment in the ZHU River Delta region from Hong Kong processing enterprises involves textiles, home appliances, electronics and other labor-intensive industries, long-term housing is in the low end of the industrial chain, and the smile curve represents the ind ustry chain, profit space of production at both ends of the industry chain is design and sales but few engaged in processing trade enterprises. At present, only $25 \%$ of enterprises in the ZHU River Delta are engaged in technology and capital intensive $\mathrm{R} \& \mathrm{D}$ and marketing, but $67 \%$ of the enterprises are still engaged in labor-intensive processing and manufacturing. These kind of labor-intensive industries are mostly in the simple processing and assembly processing trade, in the $\mathrm{R} \& \mathrm{D}$, design, manufacture, transportation, warehousing, and sales of the industrial chain involve only profit space, the smallest of the manufacturing sector. For a long time, although the import and export of ZHU River Delta region accounted for a very large proportion, due to the import and export of $70 \%$ in the ZHU River Delta region are driven by the processing trade, so the import and export amount of ZHU River Delta region is huge, but the profit growth is relatively slow.

\section{The problem of processing trade transformation and upgrading in thu river delta region}

Enterprise lack of technological innovation ability. Technological innovation is a real effective method for the transformation and upgrading of processing trade in the ZHU River Delta region, but there are few technological innovations in the ZHU River Delta region, and the proportion is less than $30 \%$. An important indicator of technological innovation is the amount of patents, and this indicator is not high in the PRD [5]. In 2008, among a total of 47098 patents in the ZHU River Delta region, the largest number was 19,198 in Shenzhen, and Zhaoqing had the minimum of only 268. In 2009, among a total of 55367 patents granted, although the number increased, its number did not increase. At the same time, the ZHU River Delta region lacks the core and key exchange and training opportunity, the degree of technology spillover is not expected, which has caused the difficulties of transformation and upgrading.

Domestic shortage, the impact of the international market fluctuations on the PRD industry development. The economic development of the ZHU River Delta has been the shortage of domestic demand and the narrow economic hinterland. The economic area is outside the main form, and processing compensation trade is one of the important forms of ind ustrial development. However, in 
recent years, the dollar against the RMB exchange rate continues to decline, the foreign product sales of ZHU River Delta to the relevant enterprises are sluggish and the cost prices continue to raise and domestic and light industrial products market by the buyer turn for the dual pressures of the seller. Some enterprises were in insolvency or on the verge of bankruptcy. The new industries, such as the IT industry, did not develop enough to compensate for this defect, which had a negative impact on the future development of the PRD ind ustry. Secondly, due to the proportion of high income earners in the total income, the average propensity to consume is low, this will inevitably lead to the decline of the residents consumption propensity, so that consumer demand is not busy, it is not conducive to stimulating domestic market in the processing trade in the ZHU River Delta region, and promotes the transformation of trade upgrade.

Lack of compound talents. The shortage of compound talents has become the bottleneck restricting the industrial upgrading of the ZHU River Delta region. "Industrial upgrading requires a lot of high skilled personnel and high quality labor force. However, in recent years, the ZHU River Delta region not only sustained "shortage of workers", but also the lack of high skilled personnel and outstanding management talents. The traditional processing trade of the ZHU River Delta region has a lot of difficult labor, which is difficult to transform into a mature labor force in a short time, which means the lack of the impetus to the transformation and upgrading of the original power. At the same time, the processing trade enterprises in the ZHU River Delta region pay no attention to communicate with local scientific research organizations and universities talent. As a result, the enterprise transformation needed to upgrade high-tech talent and skilled labor can not get enough in the market, the transformation and upgrading of course also be difficult to sustain.

\section{The strategy of processing trade transformation and upgrading in the thu river delta region}

Correctly guide the direction of enterprise development, and guide capital to technology intensive industries. At present, the processing trade in ZHU River Delta region is in the important stage of the transformation and upgrading, and the government provides investment or policy support to guide the transformation and upgrading of processing trade enterprises. Through the development of technological innovation as the leading mode, effectively overcome the drawbacks of the development of science and technology and economic development, the capital to the technology intensive industries, access to higher economic benefits. Encourage enterprises to focus on the development of key value module, improve the level of technological innovation in enterprises of processing trade, stimulus money from low technology level of processing trade, transfer to a higher level of processing trade to. At the same time, the support processing trade enterprises to expand the domestic market, in order to provide space for the development of regional industrial. Use of geographical advantages, strengthen cooperation with the surrounding areas such as Hong Kong, Taiwan, and give full play to their respective advantages, expanding trade channels.

Improve the ability of independent innovation, improve the added value of the product. Due to the lack of the independent innovation ability in the ZHU River Delta region products "made in China" are mostly in the low end of the industry value chain of manufacturing with shortage of core technology, less independent intellectual property rights and high technology products, and in the international market brand low proportion. It is necessary to improve the ability of independent innovation; the first is to actively develop the funded high-tech enterprises in ZHU River Delta region. Through independent innovation mechanism, guide the processing trade to transform from simple OEM (OEM) to design and manufacture (ODM), its own brand (OBM), eventually to change the general form of trade. From the low-end manufacturing, change the smiling curve of the two ends. Secondly, to fully play the roles of existing institutions and research institutions innovation incubator, enterprises should vigorously promote the enterprise through research and development activities of the transformation and upgrading of experience. Finally, through technological innovation, syste $\mathrm{m}$ 
innovation and management innovation, enterprises should upgrade the traditional processing trade industry, in order to form a modern level of processing trade mode.

Inte rnal and external, attract, retain and cultivate high-quality personnel. Talent is the basis for the development of the industry in the ZHU River Delta region, so the enterprises should establish a sound employment mechanism to attract and retain talents, and give full play to their respective potentials. The ZHU River Delta region is rich in resources; enterprises should make full use of school resources, and cooperate with schools to build the school internship base. Establish teaching research practice base, use the strength of the enterprise and the school's existing resources. Relying on universities and community education resources, establish and perfect the combination of "education and training" mode as soon as possible to enhance the manufacturing human capital value, in order to create a high-quality manufacturing labor force and reserve team. In the process of transformation and upgrading, enterprises should tilt and pay attention to talent cultivation to a greater degree, especially in the industrial chain at both ends of the professionals, such as brand design, technological innovation and logistics management. A large number of advanced skilled personnel will compensate for the weakening of the traditional comparative advantage of the $\mathrm{ZHU}$ River Delta region processing trade, and further transform the innovation results into economic benefits.

Accelerate the development of processing trade industry cluster. The transformation and upgrading of the processing trade in the ZHU River Delta region have inherent relations with the industrial cluster, which reveal the effective way of the transformation and upgrading of processing trade, that is, the industrial cluster strategy. To take full advantage of the region's industry, by virtue of science and technology together with the advantage of location in the ZHU River Delta region, some industries are chosen, and the processing trade industry cluster is pointing to the science and technology innovation system, establish multinational corporation R \& D Center gathered intensive processing trade park construction, technology upgrading and technological innovation cost reduction, and improve the motivation of technological innovation of enterprises. Encourage foreign investment to the processing trade park investment, and guide foreign investment to develop high-tech park, foster new technology industries supporting production base, and upgrade the processing trade to create more good industrial space.

\section{References}

[1] Jiang Hua, Lin Li. Study on [J]. Business on the upgrading of China's ind ustrial structure of processing trade, 2009 (7): 133-135.

[2] Luo Rui. ZHU River delta industry development status quo, problems and future outlook [J]. Chinese business, 2009, (8): 168

[3] Wang Li, the development of processing trade in Guangdong province and Countermeasures [J]. economist, 2005 (7): 253-254.

[4] Lu Xiaofang, Liao Liping. Research on the strategy of healthy sustainable development of processing trade in China [J]. commercial economy, 2009 (9): 81-84.

[5] Peng Guifang. The economic aspect [J]. Economy in the process of the processing of Pearl River Delta, 2008 (10): 25-27.

[6] WIA. Pennsylvania's Targeted Industry Cluster: Agriculture and Food Production,2003

[7] Suren, K. and Wayne, T.: Economic Impacts of the Saskatchewan Agriculture and Food Cluster on the Saskatchewan Economy, Saskatoon, University of Saskatchewan, 2005: 1-64

[8] Barkley, D.L.; Henry, M.S. and Kim,Y.: Ind ustry Agglomerations and Employment Change in Non-metropolitan Areas, Review of Urban and Regional Development Studies, 1999, 
11(31):168-186

[9] Gereffi,G.International trade and industrial upgrading in the apparel commodity chain [J]. Journal of International Economics, 1999, 48(1):237-701.

[10] LAN Yong, Du Hongmei. The level and path of the upgrading of processing trade in our country [J]. Economic Forum, 2005 (10): 39-40.

[11] Liu Dexue, Bu Guoqin. Research on the upgrading of garment processing trade in China [J]. international trade, 2010 (11): 3-6. 